\title{
COMPANY VALUE IMPROVEMENT THROUGH \\ FUNDING POLICY BASED ON OWNERSHIP STRUCTURE \\ (Comparison Study at Conventional and Sharia Manufacturing Companies)
}

\author{
Jumaizi $^{*}$, Ngaijan ${ }^{2}$ \\ *Corresponding Author : \\ ${ }^{1}$ STIMART AMNI, Semarang, Indonesia. jumaizi10@gmail.com. \\ ${ }^{2}$ STIMART AMNI, Semarang. Indonesia, ngaijansmg@gmail.com
}

\begin{abstract}
The results show that managerial ownership and institutional ownership have negative and significant effects toward debt policy and company values, while debt policy have a positive and significant effects toward debt policy and company values. This phenomenon shows that shareholders from management and shareholders from institutional assess rhat debt policy may harm their position in the company, and will not give any benefit materially, it is because of Interest expense that cannot fully deduct the taxable income. Meanwhile, the debt policy is considered as positive signal of a business project that the company wants or works on, therefore the company needs a lot of funds. On the other hand, the composition of stocks ownership dominated by management and institutional shareholders is regarded as a threat in society, due to the opportunity to benefit themselves but will not benefit the society. In the end, information asymmetry still becomes a problem between individual and small shareholders, with shareholders that able to obtain important company informations such as institutional shareholders and shareholders who also take control the company management.
\end{abstract}

Keywords: Managerial ownership, institutional ownership, funding policy and company value, agency conflict

\section{INTRODUCTION}

Based on financial management point of view, one of the objectives from the company's existence is to achieve the prosperity of shareholders or owners, that can be demonstrated through the increasing value of the company (Cheung, Chung, \& Fung, 2015; Fred. J Weston $\&$ Brigham, 1994). However, there are various conflicts in the process, including conflicts in the internal of the company such as conflicts between managers and shareholders or between the shareholders and creditors, which is basically it is caused by agency relationship. Agency relationship deals with an agreement or contract in which one of the parties is more dominant or has authority in influencing the company's decision, so that the decision give benefits to the party (Jensen \& Meckling, 1976; Rünger, 2014).

In maximizing shareholder prosperity, most financiers are more likely to hand over the business and the company management to professionals (in this case managers), who understand the good corporate management strategy (Alfaraih, Alanezi, \& Almujamed, 2012). Managers, with their authority, are required to work for the company and maximize the company value so that the welfare of the company can be achieved. In addition, managers are also required to make a profit which will then be distributed to the shareholders as dividend (Sucuahi \& Cambarihan, 2016). On the other hand, through authority and direct involvement, the manager may make decisions which can give benefit to himself even if it will sacrifice the interests of the shareholders. It is called conflicts in the agency relationship (agency conflict) (Jensen \& Meckling, 1976). 
This can occur due to asymmetry information between managers and the owner of the company, that is the imbalance of information known by the two parties (Rizqia, Aisjah, \& Sumiati, 2013). Thus, the managers' decisions are probably the decisions which give benefit to them, such as improving the status and salary.

As the result of agency issues, there will be a cost to reduce the conflict, called agency cost (Jensen, 1986). Agency cost is an expense uses to supervise the movement of managers by shareholders. Efforts to reduce the agency cost can be done by several approaches, one of them is increasing managerial ownership so that the interests of management and shareholders are more aligned, because the manager know that the shareholder's position, that the wrong decisions may cause company's losses. (Hasnawati \& Sawir, 2015; Indra E. Tjeleni, 2013; Murtiningtyas, 2012).

Efforts to increase supervision mechanisms from external parties can also be done by activating the monitoring through institutional ownership (Hasnawati \& Sawir, 2015; Indra E. Tjeleni, 2013; Listyani, 2003; Murtiningtyas, 2012; Velury \& Jenkins, 2006). Institutional ownership will trigger the emergence of more optimized manager performance. Companies that have large institutional ownership structures demonstrate their dominance in monitoring management performance. The greater institutional ownership structure, the utilization of company assets can be more efficient, so that it can prevent the wasteful behavior by management (Khanna \& Palepu, 2000; Nix \& Chen, 2013).

The phenomenon of Indonesia's manufacturing industry development demonstrates a bright prospects in the future. Thus requires an efficient mechanism to minimize the agency conflicts among shareholders. One of the mechanism is through the structure of shareholder by internal and external parties. However, the dominant managerial ownership can also threaten other shareholders because the external management will have difficulties in controlling the manager's performance. (Wahidahwati, 2002). While the institutional ownership is considered incapable in minimizing agency conflicts and maintaining the company value (Mokhtari \& Makerani, 2013). This is contrary to the previous explanation where managerial ownership and institutional ownership are deemed to minimize agency conflicts which can increase the company value in the market.

The use of debt makes the company have responsibility for periodic loan installments, where it can control the free cash flow, and prevent the manager from doing waste actions, and triggers managers to look for the most profitable investments or businesses. Increasing the source of funds derived from debt can also minimize the agency cost (Baker \& Martin, 2011, pp. 18-19; Putu Anom Mahadwartha \& Jogiyanto Hartono, 2002). It can reduce the desire of managers to use cash flow for activities that are not optimal. Thus the existence of debt is considered to be able to control the role of managerial ownership which can maintain the good value of the company. The debt policy intervention and the impact of ownership structures on the increase of company value are the hypotheses in this research.

\section{LITERATURE REVIEW}

\section{Company Value}

Company value is a certain condition that has been achieved by a company as a representation of community's trust in the company after a few years of process, since the 
company was established to present. The community's trust can be seen by their willing to buy shares of the company at a certain price according to their perception and belief. The increase company value is an achievement, as the wishes of the owners, because by the increase company value, the prosperity of the owners will also increase, and this is the duty of the manager as an agent that has been trusted by the company owners to run the company (Riyanto, 2008). The company value is very important because with the high company value, it will be followed by the high prosperity of shareholders (Brigham, Gapenski, \& Brigham, 1997; Martin-Reyna \& Durán-Encalada, 2012). The higher stock price, the higher company value. The wealth of shareholders and companies is presented by the stock market price which also a reflection of the investment decision, financing, and asset management. The company value in this reseach used price book value which illustrates how much the market appreciates the stock book of a company. Companies that run well, generally have the ratio of price book value above one, which reflects the stock market price is greater than the value of the book. The high price book value reflects the prosperity of the shareholders, where prosperity for shareholders is the main goal of the company (Weston \& Brigham, 1977).

\section{Ownership Structure Managerial Ownership}

Managerial in a company is a party that is active in making decision to run the company. The parties are those who sit on the commissioners board, and the directors board of the company. The existence of managers have different backgrounds, such as representing the shareholders institutional, professional personnel appointed by shareholders in the GMS (General Meeting of Shareholders), those who sit in line with the management of the company because they also have shares. The managerial ownership structure is the proportion of ordinary shares owned by management. With managerial ownership, the manager will directly feel the impact of every decision taken including in determining the company's debt policy (Hasnawati \& Sawir, 2015; Indra E. Tjeleni, 2013; Murtiningtyas, 2012). The increase of managerial ownership will make personal wealth management increasingly tied to the company's wealth so that management will strive to reduce the risk of wealth loss. With the increase of managerial ownership percentage, the manager is motivated to improve performance and responsible to increase the prosperity of shareholders.

\section{Institutional Ownership}

The level of shareholding by a fairly high managerial can give bad effect on the company (Wahidahwati, 2002). This is because the manager has a great voting right for their very high ownership, so they have a strong position to control the company. As a result, external shareholders will have difficulty to control the manager's actions.

In order to overcome the weakness above, it is advisable to have a supervisory mechanism within the company. One of the mechanisms is by enabling monitoring through institutional investors (Hasnawati \& Sawir, 2015; Indra E. Tjeleni, 2013; Listyani, 2003; Murtiningtyas, 2012; Velury \& Jenkins, 2006). Institutional ownership is the ownership of shares by institutional parties such as banks, insurance companies, investment company and 
other institutions (Wahidahwati, 2002). With institutional ownership by investment companies, banks, insurance companies and other institutions, the company will encourage the emergence of more optimal supervision towards manager's performance (Khanna \& Palepu, 2000; Nix \& Chen, 2013). Institutional ownership is important in supervising the behavior of managers, so managers are more cautious in decision making.

\section{Funding Decisions}

In an effort to manage and run the company's activities, the manager needs funds for its business expansion activities. The funding sources can be obtained from internal and external capital. Internal capital derived from retained earnings while external capital from the company's capital or debt.

The use of debt-with interest has its advantages and weaknesses. The advantages of debt use for companies include:

1. Interest expense reduces tax expense.

2. Creditors only get relatively fixed interest so that excess profit is a claim for the company owner.

3. Creditors have no voting rights so the owner can control the company with smaller funds.

The use of debt also has a weakness because the higher debt will increases the risk and if the company is not good, the operating income will be low and not enough to cover the cost of interest so the owner's wealth will be reduced. In extreme conditions, such losses can harm the company because it can be threatened by bankruptcy (Adenugba, Ige, \& Kesinro, 2016; Rahim, Yaacob, Alias, \& Nor, 2010).

On the other hand, debt can be used as one of the supervision tools in controlling agency conflicts. Companies with great free cash flow encourage managers to do waste and use them for personal interests. Debt will lower the cash flows, and it lowers the chances of management in making waste. Debt policy also causes the company to be monitored by the creditors. Strict supervision within the company will cause the manager to act in accordance with the interests of the creditor or shareholder. Therefore, the company should look for a balance point so that the use of debt can be done optimally so that losses suffered by the creditors, managers and shareholders can be reduced as minimum as possible (Alonso, De, Iturriaga, \& Rodryguez, 2005; Altan \& Arkan, 2011; Baker \& Martin, 2011; Khamis, Salleh, \& Nawi, 2012; Obradovich \& Gill, 2012; Putu Anom Mahadwartha \& Jogiyanto Hartono, 2002)

\section{Sharia Companies in Indonesia}

Indonesia is a country with Muslim as the majority. Therefore, the industrial sector in Indonesia try to fulfill the halal business so that the Muslim community in Indonesia can be more calm when about to engage with these companies (Rivai, Firmansyah, Veithzal, \& Rizqullah, 2010). In general, the application of Islamic sharia principles in the capital market industry, especially on stock instruments, is based on the assessment of shares issued by each company.

The fiqh experts argued that stock can be categorized fulfill the sharia principles if the company activities do not include things that are prohibited in Islamic rules, such as: alcohol, gambling, the production with pigs as the raw material, pornography, conventional financial 
services, and conventional insurance (Rivai et al., 2010, p. 534). So that in 2007 Indonesian Market and Financial Institution Supervisory Agency (BAPEPAM) started to publish Sharia Effect List (DES) which contains of companies list in Indonesia according to sharia principles (Indonesia Stock Exchange, 2015). The Sharia effect list is keep updated by Financial Sercive Authority (OJK).

The criteria that must be fulfilled by issuers in order to enter the Sharia Effect List are as follows (Financial Ferivices Authority, 2014):

1. The business activities are not in contradiction with sharia principles as regulated in IX.A.13, for not conducting business activities as follows

a. Gambling and games related with gambling.

b. Trading without service/goods delivery.

c. Trading with fake offer/request

d. Bank with interest based.

e. Financial companies with interest based.

f. Trading which contains uncertainty elements (gharar) and / or gambling (masyir), including conventional insurance.

g. Producing, distributing, selling and/or provide harem goods/revice (harem lidzatihi), harem goods or service not because of the substance (haram li-ghairihi) determined by DSN-MUI; and / or, goods or services that are morally harmful.

h. Conducting transaction with bribe elements (risywah).

2. The total of debt ration with interest based compared to the total of equity can not exceed $45 \%$.

3. The ratio of total interest income and other non-halal income compared to the business income and other income for no more than $10 \%$.

The higher starndardized of sharia companies makes small possibility of a bad company performance. Moreover, if the authority ownership in the company is also dominated by parties that support the implementation of Sharia business. It becomes the basis of a better pattern possibility in sharia companies compared to conventional companies, including manufacturing companies. Thus, this research is about to involve "sharia" as a controlling variable towards company policy and values.

\section{Research Framework}

One of the funding sources comes from debt. The use of debt can reduce excess cashflow within the company and reduce agency conflicts. By debt, the company must make periodic payments on the interest and basic loans (Baker \& Martin, 2011, pp. 18-19; Putu Anom Mahadwartha \& Jogiyanto Hartono, 2002). This can reduce the desire of managers to use cash flow for activities that are not optimal.

Efforts to reduce the agency cost can be done by increasing managerial ownership and institutional ownership. Managerial ownership causes managers to be cautious in using debt and to avoid opportunistic behaviour because managers also suffer the consequences of high interest costs and managers tend not to dislike risk (Weston \& Brigham, 1977). The increase of managerial ownership, will reduce the use of debt by the company. 
The presence of institutional investors will drive to more optimal supervision towards management performance (Swandari, 2006). An effective supervision by institutional will lead to decrease of debt use due to the role of debt as one of the supervision equipment that has been taken over by foreign institutional.

Based on the explanation above the research model can be described as follows:

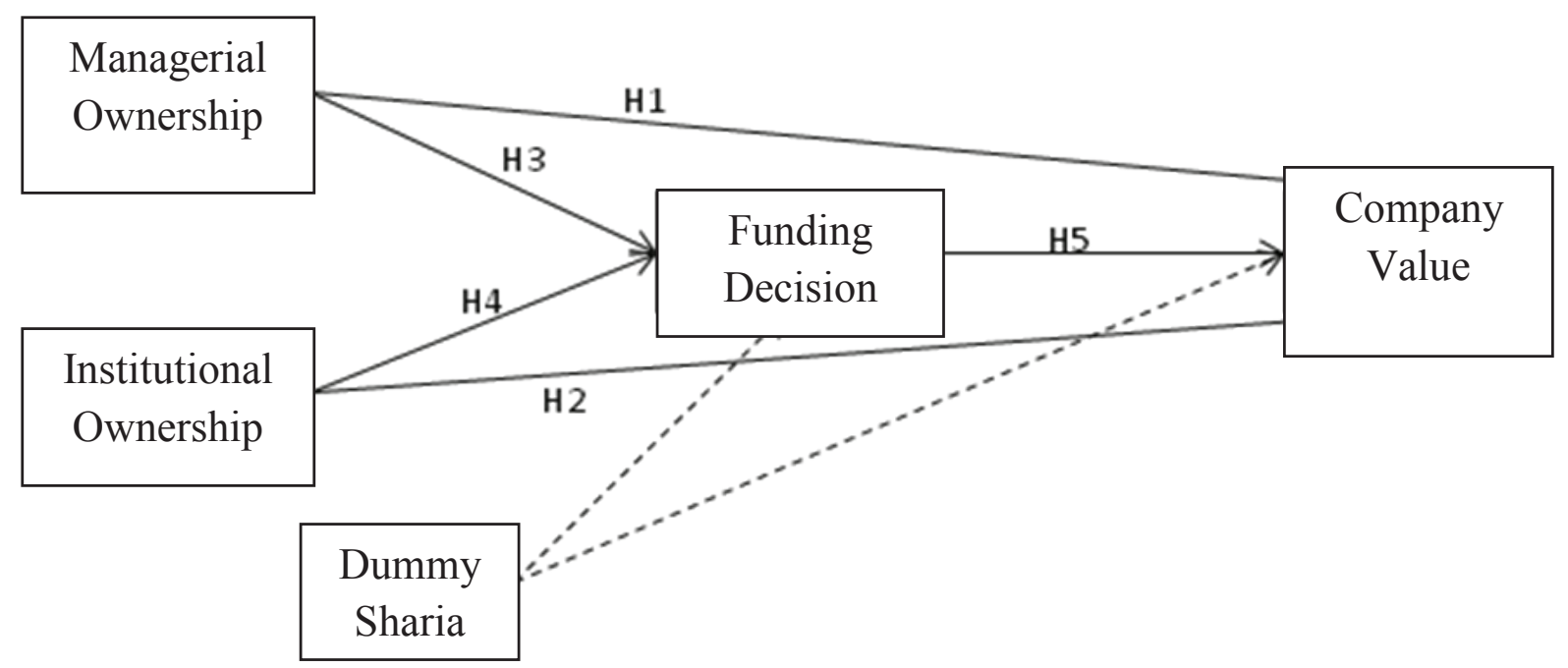

Figure 1. Research Framework

\section{Research Hypotheses}

Referring to the problem formulation, the theories and some previous studies, so the hypotheses that will be tested in this study are:

$\mathrm{H}_{1}$ : Managerial ownership positively influenced the company value

$\mathrm{H}_{2}$ : Institutional ownership positively influenced the company value

H3 : Managerial ownership negatively influenced the debt policy

H4 : Institutional ownership positively influenced the debt policy

H5 : The debt policy influences the company value

\section{RESEARCH METHOD}

The object of this research focused on manufacturing companies in Indonesia. The analysis process used samples of manufacturing companies in Indonesia listed on the Indonesia Stock Exchange (IDX) from 2012 to 2016. Samples in the research at least have qualified to publish the full annual financial report as well as the needs of research, as a source of research data collection. Therefore, there were at least 119 Indonesian manufacturing companies that can be used in this research.

\section{Variable and Indicator}

The research variable consists of dependent variables (company values), independent variables (the ownership structure which is divided into managerial ownership and institutional ownership). 
Company Value. The company value in this research is measured by the PBV (price book value) as the market ratio used to measure the performance of the stock market price towards book value:

$$
\mathrm{PBV}=\text { Stock price / Price book value }
$$

Managerial Ownership. Managerial ownership is a measure of the stock percentage owned by the directors board, management, commissioners or any party which directly involve in the decision making of the company.

Institutional Ownership, The proportion of shares owned by the institution at the end of the year measured in \%. This variable represents the level of stock ownership by domestic institutions within the company.

Funding Policy. Funding policy variable is assessed by using debt to equity ratio (DER) indicator, a financial ratio that compares the company's total debt to total capital, with a formula (Obradovich \& Gill, 2012):

\section{Debt to Equity Ratio $=$ Total debt $/$ Total equity}

\section{Analysis Technique}

Model uses data regression panel (Ghozali \& Ratmono, 2013). Analysis begins with determining the first and second regression models (Widarjono, 2009, p. 231), then followed by classic assumption test for panel data, then conduct hypotheses test using t-test and influence test indirectly using sobel test. The equation formula on the first and second models is as follows.

\section{Model I :}

$\mathrm{Y} 1=\alpha+\beta 1 \mathrm{X} 1+\beta 2 \mathrm{X} 2+\beta 3 \mathrm{X} 3+\varepsilon 1 \quad$ or

$\mathrm{DER}=\beta 1$ d_sharia $+\beta 2 \mathrm{MAN}+\beta 3 \mathrm{INST}+\varepsilon 1$

Model II :

$\mathrm{Y} 2=\alpha+\beta 4 \mathrm{X} 1+\beta 5 \mathrm{X} 2+\beta 6 \mathrm{X} 3+\beta 7 \mathrm{Y} 1+\varepsilon 2 \quad$ or

$\mathrm{PBV}=\beta 4 \mathrm{~d} \_$sharia $+\beta 5 \mathrm{MAN}+\beta 6 \mathrm{INST}+\beta 7 \mathrm{DER}+\varepsilon 2$

\section{RESULT}

\section{Descriptive Statistics Analysis}

This research uses annual financial report data of manufacturing companies in Indonesia from 2012 to 2016. The data is based on the completeness of financial statements published by each company. So the total data obtained is 119 companies for 5 periods ( $\mathrm{n}$ $=595$ data). From the collection of 119 data for 5 periods, it can be conducted a simple analysis, which is a descriptive statistical analysis. Descriptive data processing results can be seen in table 1 . 
Table 1. Descriptive Analysis

\begin{tabular}{lllll}
\hline & PBV & DER & MNJ & \multicolumn{1}{l}{ INST } \\
\hline Mean & 2.451529 & 1.047779 & 4.660156 & 70.35538 \\
\hline Median & 0.931766 & 0.865051 & 0.001000 & 75.00000 \\
\hline Maximum & 62.93107 & 70.83159 & 89.44444 & 98.95830 \\
\hline Minimum & -9.027196 & -31.78137 & 0.000000 & 0.000000 \\
\hline Std. Dev. & 6.463365 & 4.342721 & 13.10778 & 20.73299 \\
\hline Skewness & 6.276585 & 5.077003 & 4.239096 & -1.158233 \\
\hline Kurtosis & 47.73852 & 130.9569 & 22.56812 & 4.880236 \\
\hline \multicolumn{5}{c}{} \\
\hline Sum & 1458.660 & 623.4286 & 2772.793 & 41861.45 \\
\hline Sum Sq. Dev. & 24814.40 & 11202.38 & 102057.4 & 255334.9 \\
\hline \multicolumn{5}{r}{} \\
\hline Observations & $\mathbf{5 9 5}$ & $\mathbf{5 9 5}$ & $\mathbf{5 9 5}$ & \\
\hline
\end{tabular}

Source: Output Eviews

According to table 1, it can be known that manufacturing companies mostly have price to book value under the value of the book. It is shown from the middle value of the stock price ratio per book value of 0.9317 while the average value is 2.4515 . The spread can also indicate that there are several companies that have a high reputation among the community, the sample of this research also companies that have a lower share value than the book value.

The same thing also occurs in the debt ratio towards capital, but there is a big difference. The average value of debt ratio is 1.0477 , while the middle value is lower than the average value of 0.865 . For the management ownership factor, almost all companies have shareholders who are also part of the company's managerial. Nevertheless their ownership is very small, and only a small part of the company whose management is also a shareholder. The institutional ownership conditions of manufacturing companies have different conditions. It is shown from the middle value of institutional ownership ratio is greater than the average value. In other words, the majority of manufacturing companies have a capital structure dominated by institutional shareholders.

This can be understood because the development of manufacturing industry in Indonesia has a great opportunity in the coming era. So that other companies who realize the potential prefer the manufacturing stock as the allocation of their excess funds. Moreover, the investment decision of other companies has been based on the analysis and consideration of financial experts of each investor company, where it is convincing that the manufacturing sector companies are still a favorite for institutional investor.

\section{DISCUSSION}

The hypothesis testing in this study was conducted after the determination of a regression equation model and classical assumption test. The regression equation model has been determined to use Fixed Effect Model (FEM) after passing through Chow Test and Hausman Test. While this research panel data has also fulfilled the classical assumption test in the form of multicolinearity test and heteroscedasticity. The research data is processed using 
the help of Eviews 10 program. The hypotheses result is divided into table 2. For the first regression, and in table 3 for second regression.

\section{Tabel 2. The Fit Model of First Regression}

Dependent Variable: DER

Method: Panel EGLS (Cross-section weights)

Sample: 20122016

Periods included: 5

Cross-sections included: 119

Total panel (balanced) observations: 595

Linear estimation after one-step weighting matrix

\begin{tabular}{crrrr}
\hline Variable & Coefficient & Std. Error & t-Statistic & Prob. \\
\hline C & 0.744713 & 0.062242 & 11.96488 & 0.0000 \\
MNJ & 0.004263 & 0.001602 & 2.661437 & 0.0080 \\
INST & 0.006528 & 0.000865 & 7.551350 & 0.0000 \\
D_SHARIA & -0.619098 & 0.027257 & -22.71363 & 0.0000 \\
\hline
\end{tabular}

Note: (significance of $10 \%$ or 0.1 )

\section{Tabel 3. The Fit Model of Second Regression}

Dependent Variable: PBV

Method: Panel Least Squares

Sample: 20122016

Periods included: 5

Cross-sections included: 119

Total panel (balanced) observations: 595

\begin{tabular}{crrrr}
\hline Variable & Coefficient & Std. Error & t-Statistic & Prob. \\
\hline C & 1.563727 & 1.293812 & 1.208620 & 0.2273 \\
DER & 0.203430 & 0.060614 & 3.356169 & 0.0008 \\
MNJ & -0.025808 & 0.026419 & -0.976888 & 0.3290 \\
INST & 0.004629 & 0.016659 & 0.277888 & 0.7812 \\
D_SHARIA & 1.163291 & 0.537850 & 2.162856 & 0.0310 \\
\hline
\end{tabular}

Note: (significance of $10 \%$ or 0.1 )

\section{Managerial Ownership towards Company Value}

Table 3. shows the existence of managerial ownership relationship (MNJ) on the company value (PBV), with negative influence of regression coefficient for -0.025808 . This indicates that small managerial holdings will be able to increase the company value. In other words, companies that are not dominated by shareholders who are also a manager will be assessed better. in the market.

Manufacturing company is a company that has a large prospects of business development in Indonesia, because Indonesia is a developing country with a very high population. It makes the consumer market becomes very tempting, not only for investors and prospective investors, but also for management. With the double power of management that is also the owner of 
the shares, it is feared, will make the company policy not be able to favoring the interests of investors or individuals or small shareholders. The results of this research are not in accordance with the hypotheses, because the the influence of managerial ownership is not appropriate to the hypothesis (negative). In other words, hypothesis $\mathbf{1}$ is rejected.

Managerial ownership that is too dominant can also threaten other shareholders because external parties management will have difficulty in controlling the managers performance (Sukirni, 2012; Wahidahwati, 2002)

\section{Institutional Ownership towards Company Value}

According to table 3, it can be known that institutional ownership is able to influence the company value. It complies the hypothesis research which stated that by institutional ownership, the company value will also increase. In the other words Hypothesis $\mathbf{2}$ is rejected because the influence is not significant.

The existence of ownership by institutional is essentially showed the interest of large and professional investors toward compan, where it gives a good signal that the company have a good and profitable performance also business opportunity in the future. Moreover, company with bigger institutional stocks (5\%) indicates the ability to monitor the management. The higher institutional ownership, the more efficient company active utilization. Hence, the proportion of institutional ownership can be categorized as prevention in the wastage by management (Alfaraih et al., 2012; Jung \& Kwon, 2002). The positive and significant relationship also in accordance with the previous research (Hasnawati \& Sawir, 2015; Indra E. Tjeleni, 2013; Khanna \& Palepu, 2000; Listyani, 2003; Murtiningtyas, 2012; Nix \& Chen, 2013; Velury \& Jenkins, 2006).

\section{Managerial Ownership towards Debt Policy}

The third hypothesis test refers to the first regression results presented in table 2 . Based on the table 2, it is revealed that the existence of management that also has shares in related companies tends to want a higher debt policy. It is in accordance with the hypothesis on this research, also in accordance with previous research (Wahidahwati, 2002). Therefore it can be said the hypothesis 3 is rejected.

Overuse of debt as a source of funding will increase risk when the company's condition is not good. As the operating income will be low and not enough to cover the cost of interest, it will eventually impact the wealth loss of the owner. In extreme conditions, such losses can harm the company because it can be threatened by bankruptcy. Moreover, the burden of debt (such as interest) that can be used as a deduction for taxable income has a maximum limit, so that too high funding from debt will ultimately harm the company itself.

Efforts to reduce the agency cost can be conducted by increasing managerial ownership and institutional ownership. Managerial ownership causes managers to be cautious in using debt and to avoid opportunistic behaviour because managers also suffer the consequences of high interest costs and managers tend to dislike risk (Weston \& Brigham, 1977). The increase of managerial ownership, will reduce the use of debt by the company. 


\section{Institutional Ownership towards Debt Policy}

According to table 2., it is known that institutional ownership has a positive and significant relationship to debt policy. It is not in line with the research hypothesis that institutional ownership has a positive influence towards debt policy. Thus, it can be concluded that the hypothesis $\mathbf{4}$ about institutional ownership has a positive influence on debt policy is accepted.

The institutional ownership which support the funding policy from debt strengthen the controlling effort which legalized by law in order to control the company, so that it can minimize fraud among employees (people in the company). Through the increase number of supervisor (in this case is the creditors or lender, such as bank), will improve the quality and accountability of company performance, because it is supervised by many parties.

\section{Debt Policy towards Company Value}

Based on table 2, it is revealed that debt policy (DER) has a positive and significant influence towards company value. This is in accordance with the research hypothesis stated that debt policy affects the company value. In other words, hypothesis 5 is accepted. The ability of debt policy in influencing the company value has also been proven by some previous researchers (Adenugba et al., 2016; Alonso, De et al., 2005; Altan \& Arkan, 2011; Farooq \& Masood, 2016; Rahim et al., 2010).

In this research, debt policy can increase the company value (Alonso, De et al., 2005; Altan \& Arkan, 2011; Farooq \& Masood, 2016). Company value is a certain condition that has been achieved by a company as a representation of community's trust to the company after a few years of process, since the company was established to present. The increase of company value is an achievement, as the wishes of owners, because by the increase of company value, the prosperity of the owners will also increase, and this is the manager's duty as an agent that has trusted by the owners of the company to run their companies. (Riyanto, 2008) The company value is very important because with the high company value, it will be followed by the high prosperity of shareholders (Brigham et al., 1997). The higher stock price, the higher company value will be. The company's wealth and shareholders are presented by market price of the shares which are a reflection of the investment decision, financing, and asset management..

The increase of company value as a form of positive response to debt policy, can be interpreted as public acceptance of the company's decision to increase debt. It is considered as a form of investment or new project undertakes by the company, therefore it requires additional capital. With the vision of the company's business plan with the addition of capital, it will increase public interest in the company.

\section{Intervening Test or Sobel}

Direct and indirect influences of independent variables toward the company value are analyzed using path analysis, which is re-tested with sobel test. The sobel test is conducted twice, in order to test the managerial ownership relationship to the company value through the debt policy which is presented in Figure 2, and the institutional ownership relationship to the company value through debt policy which is presented in Figure 3. 


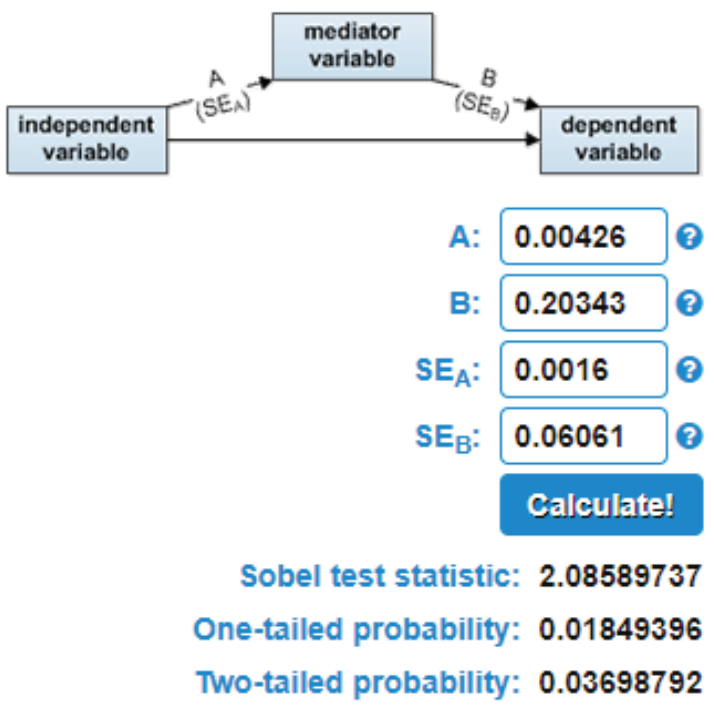

Figure 2. The sobel test in the relationship of managerial ownership towards company value through debt policy

Based on the sobel test results, it can be concluded that debt policy is able to be a broker in the impact of managerial ownership of company value. This indirect relationship is a partial indirect relationship, because managerial ownership also has a direct impact on the company value.

The management that has shares in the company has complete information related to the company's internal, so it can be said as a shareholder who deeply understands the condition of the company. Not only that, shareholders who are also part of the management not only have a voice to make decisions for the company, but also have the authority directly in making decisions, including small decisions for internal company. One of the decisions is financing policy through debt. Management certainly has a more comprehensive and wellplanned funding strategy so that it can ultimately increase the value of the company, which is the purpose of shareholders as well as the company.

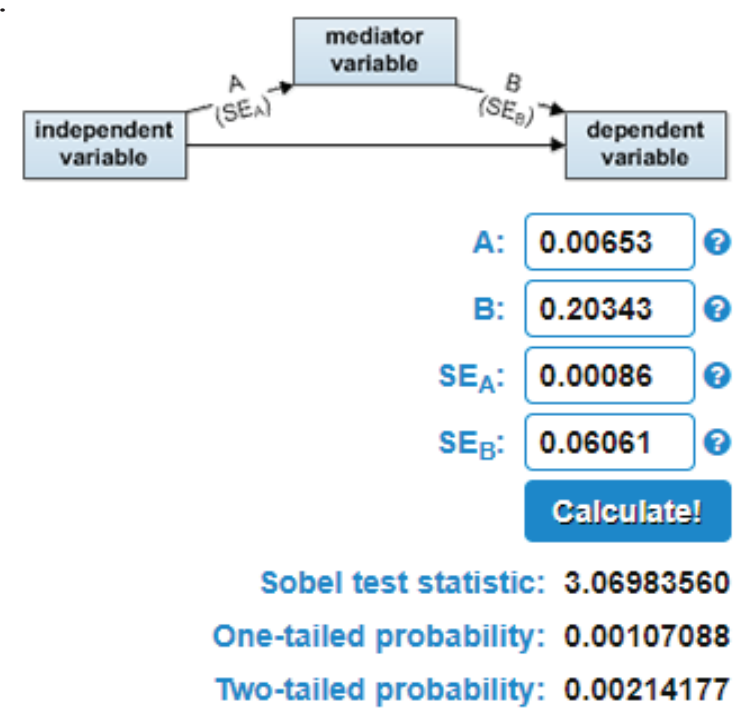

Figure 3. The sobel test in the relationship of institutional ownership towards terhadap company value through debt policy 
Figure 3 shows that debt policy can be an intermediary for institutional ownership impacts towards company values. This indirect relationship is partial, because institutional ownership has a direct relationship to the company value.

A debt financing policy is a policy that may affect shareholder capital ownership percentage. Thus, in general, the funding decision from a high debt is necessary for the consideration of shareholders. In other words, debt policy decisions are influenced by institutional ownership, as stockholder who have an ability or a more complete knowledge related to investment compared to individual shareholders.

\section{Controlling Variable}

Controlling variable in this research is in the form of dummy, to distinguish between manufacturing companies in accordance with sharia principles with manufacturing companies that in its execution has not been in accordance with sharia principles. In table 2 and 3 indicates that this dummy variable has a significant impact on the endogenous variables (the funding policy and the company value). The impact of dummy variables on the funding policy indicates a negative relationship, which means a manufacturing company that fulfill the sharia principles tends to minimize funding policy through debt. This is in line with one of the terms in sharia company, that there is a limit on the use of capital as a debt, as explained in the literature review. The role of dummy variable towards company's value has a positive correlation. It means that the company value in accordance with sharia principles is better than the value of conventional manufacturing companies (which is not in accordance with sharia principles). Thus, the strengthening of sharia companies has better quality and image than conventional manufacturing companies.

\section{CONCLUSIONS}

This research gave results that from 5 research hypotheses, only two were accepted. The two accepted hypotheses are managerial relationship towards debt policy, and debt policy relationship towards company value. Meanwhile the three hypotheses are rejected, because of differences in the direction of the hypothesis, with research results. While from the significance of correlation, it can be said that managerial and institutional ownership has a significant impact on both debt and company value policies, and the debt policy also has significant impact towards the company value. The test results of these influences can be concluded.

1. Managerial ownership has negative influence and significant towards company value

2. Institutional ownership has negative influence and significant towards company value

3. Managerial ownership has negative influence and significant towards debt policy

4. Institutional ownership has negative influence and significant towards kebijakan utang

5. Debt policy positive influence and significant towards company value

6. Managerial ownership has influence towards company value with debt policy as intermediary

7. Institutional ownership has influence towards company value with debt policy as intermediary

8. Manufacturing companies in accordance to sharia principles have better quality compared to common manufacturing companies. 
This phenomenon shows that both shareholders from management and shareholders from institutional, consider that debt policy can harm their position in the company, and will not give the any benefit materially, it is due to Interest expense that cannot fully be the cost of taxable income deduction. As a result, the debt policy is considered as positive signal of a business project that the company works on, therefore the company needs a lot of funds. On the other hand, the composition of stocks ownership dominated by management and institutional shareholders is considers as a threat in community, due to the opportunity to benefit themselves but will not benefit the community. In the end, information asymmetry is still a problem between individual and small shareholders, with shareholders that able to obtain important company information such as institutional shareholders and shareholders who are also takecontrol of company management.

\section{Suggestions}

The results of this result showed unexpected effects on ownership structures and capital structures toward the company value. Such relationship may occur due to the incompleteness of public's information on related company, resulting vary perceptions or negative allegations towards shareholders who have authority in company and to shareholders who have the dominant power in the company. Thus, it is necessary to improve information disclosure so that all shareholders and communities have the same information with shareholders who are also part of the management, and with the institutional shareholders who have a team and a level of ability to dig and analyze information sharper.

Meanwhile, for society and and prospective investors who have concerns about the managerial ownership intervention and institutional ownership that will only benefit themselves, but do not benefit small investors as well as community, the community and prospective investors can choose a more trusted alternative investment and investment management entrusted to the experts, such as with investments in the form of mutual funds.

\section{Research Limitation and Future Research Agenda}

The limitation of this research is only researching companies that are in the manufacturing sector, so in the future research, the object research can be expanded by involving other sectors, also comparing market trends in each sector. This research also makes debt policy indicators and capital ownership in the form of ratios, while the research results is strengthening the fact that managerial ownership, institutional ownership and debt financing policies is still needed by the company and can be stimulants to increase company value, at some level. While the high composition or ratio will harm the company in the end. Thus, in the future research, it is expected to develop more precise measuring instrument where it is not good if the ratio is too low or too high, so that the best is ratio with a certain limit. 


\section{REFERENCES}

Adenugba, A. A., Ige, A. A., \& Kesinro, O. R. (2016). Financial leverage and firms' value: a study of selected firms in Nigeria. European Journal of Business, Economics and Accountancy, 4(2), 1-19. Retrieved from http://www.idpublications.org/ejbea-vol-4no-2-2016/

Alfaraih, M., Alanezi, F., \& Almujamed, H. (2012). The Influence of Institutional and Government Ownership on Firm Performance: Evidence from Kuwait. International Business Research, 5(10). https://doi.org/10.5539/ibr.v5n10p192

Alonso, De, A. P., Iturriaga, L. F. J., \& Rodryguez, J. A. S. (2005). Financial decisions and growth opportunities: a Spanish firm's panel data analysis. Applied Financial Economics, 15(6), 391-407. https://doi.org/10.2139/ssrn.250717

Altan, M., \& Arkan, F. (2011). Relationship Between Firm Value And Financial Structure: A Study On Firms In ISE Industrial Index. Journal of Business \& EconomicsResearch, 9(9), 61-65. https://doi.org/10.19030/jber.v9i9.5636

Baker, H. K., \& Martin, G. S. (2011). Capital Structure and Corporate Finance Decisions: Theory, Evidence, and Practice. New Jersey: John Wiley \& Sons, Inc. https://doi. org/10.1002/9781118266250

Brigham, E. F., Gapenski, L. C., \& Brigham, E. F. (1997). Financial management, theory and practice. Chicago: Dryden Press. Retrieved from https://books.google.co.id/books/ about/Financial_Management.html?id=RlaOSgAACAAJ\&redir_esc $=y$

Cheung, W. M., Chung, R., \& Fung, S. (2015). The Effect of Stock Liquidity on Firm Value and Corporate Governance: Endogeneity and REIT Experiment. Journal of Corporate Finance2, 35, 211-231. https://doi.org/10.1016/j.jcorpfin.2015.09.001

Farooq, M. A., \& Masood, A. (2016). Impact of Financial Leverage on Value of Firms: Evidence from Cement Sector of Pakistan. Research Journal of Finance and Accounting, 7(9), 7377. Retrieved from https://www.iiste.org/Journals/index.php/RJFA/article/view/30307

Financial Ferivices Authority. Sharia Capital Market, Pub. L. No. KEP-24/D.04/2014, Financial Ferivices Authority (2014). Retrieved from http://www.ojk.go.id/pasar-modal-syariah/

Fred. J Weston, \& Brigham, E. F. (1994). The Basis of Financial Management Part 2. Jakarta: Erlangga. Retrieved from https://openlibrary.telkomuniversity.ac.id/pustaka/3341/ dasar-dasar-manajemen-keuangan-jilid-2.html

Ghozali, I., \& Ratmono, D. (2013). Multivariate and Econometrics Analysis Theory, Concept, and Application with Eviews 8. Semarang: Badan Penerbit Universitas Diponegoro. Retrieved from https://scholar.google.co.id/citations?user=kbmkIQQAAAAJ\&hl=en\#d=gs_

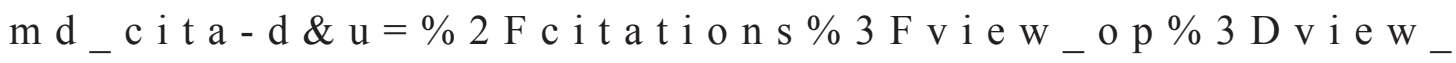
citation\%26hl\%3Den\%26user\%3DkbmkIQQAAAAJ\%26citation_for_ view\%3DkbmkIQQAAAAJ\%3ASIv7DqKytYAC\%26tzom\%3D-420 
Hasnawati, S., \& Sawir, A. (2015). FINANCIAL DECISION, COMPANY SIZE, OWNERSHIP STRUCTURE AND PUBLIC COMPANY VALUE IN INDONESIA. Jurnal Manajemen Dan Kewirausahaan (Journal of Management and Entrepreneurship), 17(1), 65-75. https://doi.org/10.9744/jmk.17.1.65-75

Indonesia Stock Exchange. (2015). Sharia Capital Market. Retrieved 16 March 2015, from http://www.idx.co.id/id-id/beranda/produkdanlayanan/pasarsyariah.aspx

Indra E. Tjeleni. (2013). MANAGERIAL AND INSTITUTIONAL OWNERSHIP THE INFLUENCE TOWARD DEBT POLICY AT MANUFACTURING COMPANIES IN INDONESIA STOCK EXCHANGE. Jurnal EMBA: Jurnal Riset Ekonomi, Manajemen, Bisnis Dan Akuntansi, 1(3), 129-139. Retrieved from https://ejournal.unsrat.ac.id/ index.php/emba/article/view/1949/1546

Jensen, M. C. (1986). Agency Costs of Free Cash Flow, Corporate Finance, and Takeovers. The American Economic Review, 76(2), 323-329. Retrieved from https://sfinm.files. wordpress.com/2013/10/agency-costs-of-fcf-jensen.pdf

Jensen, M. C., \& Meckling, W. H. (1976). Theory of the firm: Managerial behavior, agency costs and ownership structure. Journal of Financial Economics, 3(4), 305-360. https:// doi.org/10.1016/0304-405X(76)90026-X

Jung, K., \& Kwon, S. Y. (2002). Ownership structure and earnings informativeness: Evidence from Korea. The International Journal of Accounting, 37(3), 301-325. https://doi. org/10.1016/S0020-7063(02)00173-5

Khamis, M. R. bin, Salleh, A. M., \& Nawi, A. S. (2012). Compliance Behavior of Business Zakat Payment in Malaysia: A Theoretical Economic Exposition. In 8th International Conference on Islamic Economics and Finance Compliance (pp. 1-17).

Khanna, T., \& Palepu, K. G. (2000). Emerging Market Business Groups, Foreign Investors, and Corporate Governance. In Randall Morck (Ed.), National Bureau of Economic Research Conference Report. University of Chicago Press. Retrieved from https:// www.hbs.edu/faculty/Pages/item.aspx?num=851

Listyani, T. T. (2003). Managerial ownership, Debt policy and Its Influence toward Institutional Stock Ownership. Jurnal Maksi, 3, 98-114. Retrieved from http://eprints.undip. ac.id/35055/1/JMAKSI_Agt_2003_06_Theresia_Tyas_Listyani.pdf

Martin-Reyna, J. M. S., \& Durán-Encalada, J. A. (2012). Ownership Structure, Firm Value and Investment Opportunities Set: Evidence from Mexican Firms. Journal of Entrepreneurship, Management and Innovation, 8(3), 35-57. https://doi. org/10.7341/2012833

Mokhtari, Z., \& Makerani, K. F. (2013). Relationship of Institutional Ownership with Firm Value andEarnings Quality: Evidence from Tehran Stock Exchange. International Journal of Economy, Management and Social Sciences, 2(7), 495-502. 
Murtiningtyas, A. I. (2012). DIVIDENT POLICY, MANAGERIAL AND INSTITUTIONAL OWNERSHIP, PROFITABILITY, BUSINESS RISK TOWARD DEBT POLICY. Accounting Analysis Journal, 1(2). https://doi.org/10.15294/AAJ.V1I2.597

Nix, P., \& Chen, J. . (2013). The Role of Institutional Investors in Corporate Governance (1st Ed). Hampshire: Palgrave Macmillan.

Obradovich, J., \& Gill, A. (2012). The Impact of Corporate Governance and Financial Leverage on the Value of American Firms. International Research Journal of Finance and Economics, 91, 1-14.

Putu Anom Mahadwartha, \& Jogiyanto Hartono. (2002). Agency Theory Testing in Interdependence Relationship between Debt Policy with Dividen Policy | Pusat Data Ekonomi \&amp; Bisnis. In Jurnal dan Prosiding SNA - Simposium Nasional Akuntansi. Semarang. Retrieved from http://pdeb.fe.ui.ac.id/?p=9488

Rahim, A. R., Yaacob, H. M., Alias, N., \& Nor, M. F. (2010). Investment, Board Governance and Firm Value: A Panel Data Analysis. International Review of BusinessResearch Papers, 6(5), 293-302.

Rivai, V., Firmansyah, R., Veithzal, A. P., \& Rizqullah. (2010). Islamic Financial Management. Bogor: Penerbit Ghalia Indonesia.

Riyanto, B. (2008). Company Spending Basics. Yogyakarta: BPFE Yogyakarta.

Rizqia, D. A., Aisjah, S., \& Sumiati. (2013). Effect of Managerial Ownership, Financial Leverage, Profitability, Firm Size, and Investment Opportunity on Dividend Policy and Firm Value. Research Journal of Finance and Accounting, 4(11), 120-130. Retrieved from www.iiste.org

Rünger, S. (2014). The Effect of Shareholder Taxation on Ownership Concentration. In The Effect of Shareholder Taxation on Corporate Ownership Structures (pp. 5-22). Wiesbaden: Springer Fachmedien Wiesbaden. https://doi.org/10.1007/978-3-65804131-1_2

Sucuahi, W., \& Cambarihan, J. M. (2016). Influence of Profitability to the Firm Value of Diversified Companies in the Philippines. Accounting and Finance Research, 5(2), 149. https://doi.org/10.5430/afr.v5n2p149

Sukirni, D. (2012). MANAGERIAL OWNERSHIP, INSTITUTIONAL OWNERSHIP, DEVIDEN POLICY AND DEBT POLICY ANALYSIS TOWARD COMPANY VALUE. Accounting Analysis Journal, 1(2). https://doi.org/10.15294/AAJ.V1I2.703

Swandari, F. (2006). The Influence of Ownership Structure Towards The Risk Level and dan The Implication Towards Financial Difficulties of Public Banks in Indonesia. Program DoktoralUniversitas Gadjah Mada. Retrieved fromhttp://etd.repository.ugm.ac.id/index. php?mod=penelitian_detail\&sub=PenelitianDetail\&act=view\&typ=html\&buku $\mathrm{id}=31606 \&$ obyek_id $=4$ 
Velury, U., \& Jenkins, D. S. (2006). Institutional ownership and the quality of earnings. Journal of Business Research, 59(9), 1043-1051. Retrieved from https://ideas.repec.org/a/eee/ jbrese/v59y2006i9p1043-1051.html

Wahidahwati, W. (2002). The Influence of Managerial Ownership and Institutional Ownership in Company's Debt Policy: A Perspective Agency Theory. The Indonesian Journal of Accounting Research, 5(1). https://doi.org/10.33312/IJAR.67

Weston, J. F. (John F., \& Brigham, E. F. (1977). Essentials of managerial finance. Dryden Press.

Widarjono, A. (2009). Ekonometrika Econometrics Introduction and The Application. Yogyakarta: Ekonisia. 